\title{
Folkehelse og livsmestring i utdanning
}

\author{
Marit Uthus og Maria Øksnes \\ Norges teknisk-naturvitenskapelige universitet, NTNU
}

I norsk og nordisk pedagogikk har det vært en lang tradisjon for ideen om å bruke utdanningsinstitusjonene til å ruste barn og unge til aktiv deltagelse og interaksjon med sine medmennesker i et omskiftelig arbeids- og samfunnsliv. Den norske psykologen og pedagogen Helga Eng skrev i 1937 at det var en oppgave for den pedagogiske forskningen å bidra til oppgaven med å danne barn og unge som kan leve i en "på mange måter vanskelig tilværelse», en tilværelse der det er enkelt å la seg «omtumle og ødelegge». Også i dag er det mange som oppfatter tilværelsen som vanskelig. Hvordan barn og unge kan erfare at livet er verdt å leve gjennom mestring og deltakelse er en stadig pågående pedagogisk målsetting som må være gjenstand for kontinuerlig problematisering og drøfting.

Norsk og internasjonal forskning beskriver utdanningsfeltets kompleksitet og de mange oppgaver våre utdanningsinstitusjoner står ovenfor. En del av dette bildet er det mange betegner som elevers sviktende motivasjon for læring, psykiske helseplager blant unge, frafall i videregående opplæring og unge uføre. Dette er store samfunnsutfordringer som gjør seg gjeldende i våre pedagogiske institusjoner, noe som understrekes i flere artikler som i 2017 ble publisert i tidsskriftet The Lancet: Child and Adolescent Health. En oversiktsartikkel med tittelen «Free play and children's mental health" (Whitebread, 2017) antyder at det er en sammenheng mellom redusert lek i skolen, økt prestasjonspress og høyt stressnivå blant elevene. Det vises blant annet til at det er funnet konsistent evidens for at fri lek bidrar til barns fysiske og mentale helse. Denne forskningen kan med andre ord tyde på at samfunnsrelaterte utfordringer, som for eksempel mindre tid til å leke, bidrar til at barn og unge utvikler dårlig helse og erfarer at de ikke mestrer livene sine.

Den offentlige debatten om hvordan disse utfordringene skal møtes får stor oppmerksomhet, og er aktualisert i Norge med fagfornyelsen, læreplanreformen av 2020. Et sentralt stridsspørsmål er forholdet mellom barnas kunnskap, evne, kompetanse og holdning til å mestre livet sitt og de pedagogiske institusjonenes ansvar for å ivareta denne oppgaven, og utdanningspolitiske konjunkturer som bidrar til å sette agenda for skolen, slik som målstyring, systematisk kunnskapstesting, offentliggjøring 
av testresultater og kontrollsystemer. Dette er praksiser som skolens ansatte ofte oppfatter at de er forpliktet på. Innføringen av psykologiske selvhjelpsprogram i skolen der elever lærer ulike teknikker for å dempe stress og å unngå negative følelser er et eksempel på innføring av en praksis der enkeltindividet skal læres opp til å forvalte sin egen psykiske helse. Enkelte hevder dette kan forstås som en måte å fristille myndighetene for ansvar - og kravene om effektivitet og konkurranseevne kan opprettholdes eller forsterkes (Madsen, 2020; Uthus, 2017).

Vi finner det verdt å minne om at læreplaner og andre styringsdokumenter alltid må tolkes, både av den enkelte, i kollegiet og av fellesskapet. Det innebærer at det må utvikles pedagogiske praksiser som reflekterer både tidens krav og den didaktiske innsikt og erfaring som er samlet i våre utdanningsinstitusjoner. Den pedagogiske forskningens oppgave med å bidra til å danne barn og unge som kan leve i en "på mange måter vanskelig tilværelse», en tilværelse der det er enkelt å la seg "omtumle og ødelegge», må forstås som fortsatt viktig.

I dette temanummeret publiseres tre artikler som på ulike måter berører tematikken livsmestring i utdanningssystemet:

Hanne Riese, Line Hilt \& Gunn Elisabeth Søreide: «Selvregulering som pedagogisk formål: Diskursive fornyelser i 'Fremtidens skole'»

Marit Uthus: «Hva sier elever om erfaringer med å bestemme selv i læringsaktiviteter? En kvalitativ intervjustudie»

Monica Bjerklund og Ingvild Åmot: «Livsmestring i den samiske barnehagen»

Med disse bidragene håper vi å invitere til å fortsette den pågående samtalen om barns liv(-smestring) i våre pedagogiske institusjoner.

Trondheim 15.12.20

Marit Uthus

Gjesteredaktør

Maria Øksnes

Hovedredaktør 